[8] Foppen, J. W. A., (2002). Impact of high-strength wastewater infiltration on groundwater quality and drinking water supply: the case of Sana'a, Yemen

[9] Foppen, J. W. A., Naaman, M., Schijven, J. F., (2005). Managing water under stress in Sana'a, Yemen. The Arabian Journal for Science \& Engineering, 30, (2C): 69 - 83.

[10] Klimentov, P.K., (1983). General hydrology (1 ${ }^{\text {st }}$ Edn),

pp.101- 112. Russian ends Moscow.

[11] Matthess, G. (1982). The properties of Ground water (1 ${ }^{\text {st }}$

Edn), John Wiley \& Sons, New York.

[12] Mattiesen, H., (2008). Detailed chemical analyses of groundwater as a tool for monitoring urban archaeological deposits: results from Bryggen in Gergen. J. Archaeological Science, 35, $1378-1388$.

[13] Rhades, J.D and Bernstein, L., (1971). Chemical, physical and biological characteristics of irrigation and soil water, In water and water pollution (Edited by Ciaccio, L.L.), chap.3. Marcel Dekker Inc., New York.

[14] Shaki, A. A. and Adeloye, A. J. (2006). Evaluation of quantity and quality of irrigation water at Gadowa irrigation project in Murzug basin, [15] Sultan, $1.193-201$.

[15] Sulten, M. E., (1998). Characterization, classification, and evaluation of some ground water samples in upper Egypt.

[16] WHO (World Health Organization), (2006). Guideline

ing water quality recommendation.

\section{OPTIMIZATION OF NMP EXTRACTION IN 1, 3-BUTADIENE PRODUCTION LINE}

H.R.Mortaheb ${ }^{*}$, M.Mafi $^{*}$, B.Mokhtarani ${ }^{*}$, K.Khosravi $^{* *}$, F.Mashkini * Faculty of Chemical Engineering \& Physical Chemistry

"Department of Analytical Chemistry
Chemistry \& Chemical Engineering Research Institute of Iran 25 Km. Karaj High way, Pajoohesh blvd.

Keywords: $N M P$, Extraction, $n$-heptane, Distillation
${ }^{\prime}$ To whom correspondence should be addressed, khosravik @ yahoo.com

Abstract: N-methylpyrrolidone is a powerful solvent for variety of chemical processes due to it vast chemical properties. It has been used in manufacturing processes of polymers, detergents, pharmaceuticals rubber and many more chemical substances. However, it creates large amoun of residue in some of these processes which has to be dealt with. Many well known methods such as BASF in rubber producing units have tried to regenerate the solvent at the end of each run, however, there is still discarding of large amount of residue containing NMP, which over time, could cause environmental concerns. In this study, we have tried to optimize regeneration of the NMP extraction from butadiene production. It is shown that at higher temperatures NMP is separated from the residue with close to $90 \%$ efficiency, and the solvent residue proved to be is separated from the residue with

\section{Introduction}

N-methylpyrrolidone is a weak base and is an aprotic solvent with low volatility and toxicity (1).It is a powerful solvent for a wide range of chemicals, and Due to its thermal stability and its relatively high dielectric constant, it is extensively used in polymer industies (2,3).Its numerous ly used in polym ind advantageous qualities such as being environmentally friendly substance, non-carcinogenicity, noncorrosiveness, and low solvent loss have given widespread use in pharmaceutical products(4), detergent industries, polymer and rubber producing plants $(5,6)$, and many more usages are being found everyday. $\mathrm{N}$-methylpyrrolidione is used in series of processes such as degassing, distillation, and solvent regeneration in rubber manufacturing as solvent for the extraction of 1,3 -butadiene due to its high merit as a solvent, with the extracta- bility of more than $99 \%$; later the NMP and the residue is discarded or managed in a biologically equipped industrial waste treatment units which itself requires extra process and financial resources $(5,6,7)$. Recently, however, efforts have been invested in reviewing and revising the curren method. Our goal in this study was to find a way to extract NMP from the discarding residue of 1,3-Butadiene line to a higher percentage.

\section{Experimental}

\section{Instruments and Reagents}

All chemicals Methanol, Benzene, Toluene, Chloroform, Carbon tetrachloride, Xylene, ethyl 
acetate, $\mathrm{n}$-Heptane, and petroleum ether used were each solvent. First, the residue was dissolved in from Merk, and the HPLC was from Shimadzo. A $25 \mathrm{~cm}$. Shimadzo ODS column was used with the packing size of $5 \mathrm{qm}$. Water was deionized by millipore milli-Q water purifier. The BD unit purpose is to separate 1,3-Butadiene from the compounds with close boiling points with a $99 \%$ purity yields. This process is done with combination of distillation and extractions using NMP having $8.3 \%$ water content. Once the separation process is over, the un-evaporated residue from the solvent poses a great threat to the environment. Our first priority was to determine the amount of NMP in the residue then to devise a proper regeneration process and eventually a suitable discarding method.

\section{RESULTS AND DISCUSSION}

\section{Extractions}

The residue had some dissolution in various solvents such as water, Methanol, Benzene, Toluene, Chloroform, Carbon tetrachloride, Acetone, Xylene, Ethyl acetate, n-Heptane, and Petroleum ether which prompted further analyses of

Table1. N-heptane extraction of NMP at 25

\begin{tabular}{ccccc} 
Sample & $\begin{array}{c}\text { Sample weight } \\
\text { gr }\end{array}$ & $\begin{array}{c}\text { \%NMP weight } \\
\text { in sample }\end{array}$ & $\begin{array}{c}\text { \% Impurities in } \\
\text { sample }\end{array}$ & $\begin{array}{c}\text { \% n-Heptane in } \\
\text { sample }\end{array}$ \\
$\mathrm{S}_{25^{\circ} \mathrm{C}}$ & 0.5185 & 91.80 & 0.66 & 7.54 \\
$\mathrm{E}_{25^{\circ} \mathrm{C}}$ & 9.4713 & 6.01 & 0.04 & 93.95 \\
\hline
\end{tabular}

shows the HPLC analyses of both phases, as it can be seen, the impurities present in both phases have been reduced in such a way that in the $\mathrm{S}_{25^{\circ} \mathrm{c}}$ phase, 0.66 and the $\mathrm{E}_{25^{\circ} \mathrm{c}}$ phase, $0.04 \%$ weight is present while the amount of NMP in $\mathrm{S}_{25^{\circ} \mathrm{c}}$ is 91.80 and in $\mathrm{E}_{25^{\circ} \mathrm{c}}$ is $6.01 \%$ weight. Therefore , $\mathrm{n}$-heptane has selectively separated NMP from the impurities.

Extraction at near the boiling point

10.0 gram residue was refluxed in 20.0 gram n-heptane at $70^{\circ} \mathrm{c}$ for three hours. As expected, more residue material about 4.08 grams was dissolved in n-heptane at higher temperature. Again two different phases were identified, the rich organic phase $\mathrm{E}_{70^{\circ} \mathrm{c}}$ containing 19.32 gram $\mathrm{n}$ - heptane and NMP rich $\mathrm{S}_{70^{\circ} \mathrm{c}}$ containing $1.11 \mathrm{gr}$. The E phase was allowed to form two phases itself as the temperature lowered to ambient. The newly formed two phases of $\mathrm{E}_{70^{\circ} \mathrm{c}}^{\prime}\left(18.26 \mathrm{gr}\right.$.) and $\mathrm{S}_{70^{\circ} \mathrm{c}}^{\prime}$ (1.06gr.) were also analyzed using HPLC
Table2. N-heptane extraction of NMP at $70^{\circ} \mathrm{C}$ , then liquid- liquid extractions proceeded sing non-polar solvents. Extractions with Xylene produced three phases, thus rendering an unsuccessful extraction. The same procedures were used with Toluene, Ethyl acetate Methanol, and chloroform which all proved to be unacceptable where in each extraction, the amount of NMP entering the organic phase was too little or in a trace amount thus unsuccessful. The extraction with $\mathrm{n}$ heptane, however, produced better results. Though $\mathrm{MP}$ is sparingly soluble in $\mathrm{n}$-heptane, the yield was exceptionally pure, therefore, we decided to further improve the extraction using differen temperatures. Three different temperatures were determined to be used, at room, near the boiling point, and post boiling point.

\section{Extraction at room temperature}

10.0 grams of residue was mixed with 20.0 grams residue was dissolved in $\mathrm{n}$-Heptane. The dissolution ormed two phases. The upper phase identified as $25^{\circ} \mathrm{c}$ contained $23 \mathrm{ml}$. (9.47gr.), and the lower phase $\mathrm{S}_{25^{\circ} \mathrm{c}}$ contained $3.5 \mathrm{ml}$. (0.52gr.) n-heptane respectively. the residue.

\section{Extraction at post boiling point} 4.48gr.respectively,

Table3. N-heptane extraction of NMP at $100^{\circ} \mathrm{C}$

\begin{tabular}{ccccc}
\hline Sample & Sample weight gr & $\begin{array}{c}\text { \%NMP weight in } \\
\text { sample }\end{array}$ & $\begin{array}{c}\text { \%Impurities in } \\
\text { sample }\end{array}$ & $\begin{array}{c}\text { \%n-Heptane in } \\
\text { sample }\end{array}$ \\
\hline $\mathrm{S}_{70^{\circ} \mathrm{C}}$ & 1.1086 & 85.85 & 0.75 & 13.40 \\
$\dot{\mathrm{S}}_{70^{\circ} \mathrm{C}}$ & 1.0641 & 85.51 & 0.17 & 14.32 \\
$\dot{\mathrm{E}}_{70^{\circ} \mathrm{C}}$ & 18.250 & 9.2 & 0.01 & 79 \\
\hline
\end{tabular}

It can be seen from the table that the amount of impurities in extracted material is lower than the residue. The impurities in $\mathrm{S}_{70^{\circ} \mathrm{c}}$ phase is 0.75 weight percent whereas the NMP in the sample $\mathrm{S}_{70^{\circ} \mathrm{c}}$ and $\mathrm{S}_{70^{\circ} \mathrm{c}}^{\prime}$ are similar in amount to the residue. Therefore, the n-Heptane has selectively extracted NMP from

Again in this stage, 10.0 gr. residue was mixed with 20.0 gram n-heptane, and the mixture was refluxed at $100^{\circ} \mathrm{c}$. Since $\mathrm{n}$-heptane boils at $98.42^{\circ} \mathrm{c}$, a condenser was used to insure a successful condensation back to the solution. In this condition, About 6.43 gram residue was dissolved in the solvent, and the phases of $\mathrm{E}_{100^{\circ} \mathrm{c}}\left(21.86 \mathrm{gr}\right.$.) and $\mathrm{S}_{100^{\circ} \mathrm{c}}\left(0.58 \mathrm{gr}\right.$.) were identified. At lower temperature, $\mathrm{E}_{100^{\circ} \mathrm{c}}$ phase itself was divided to two other NMP and $n$-heptane rich phases, $\mathrm{E}_{100^{\circ} \mathrm{c}}^{\prime}$ and the $\mathrm{S}_{100^{\circ} \mathrm{c}}^{\prime}$ with 17.38 and

\begin{tabular}{ccccc}
\hline Sample & Sample weight gr & $\begin{array}{c}\text { \%NMP weight in } \\
\text { sample }\end{array}$ & $\begin{array}{c}\text { \%Impurities in } \\
\text { sample }\end{array}$ & $\begin{array}{c}\text { \%n-Heptane in } \\
\text { sample }\end{array}$ \\
\hline $\mathrm{S}_{100^{\circ} \mathrm{C}}$ & 0.5795 & 89.12 & 4.41 & 6.74 \\
$\mathrm{~S}_{100^{\circ} \mathrm{C}}$ & 4.4794 & 90.89 & 1.18 & 7.93 \\
$\mathrm{E}_{100^{\circ} \mathrm{C}}$ & 17.2297 & 6.59 & 0.08 & 93.33 \\
\hline
\end{tabular}

shows the HPLC analyses for $\mathrm{S}_{100^{\circ} \mathrm{c}}, \mathrm{S}^{\prime}{ }_{100^{\circ} \mathrm{c}}$ and $\mathrm{E}{ }_{100^{\circ} \mathrm{c}}$ in which the amount of impurities have been reduced dramatically. The impurities in $\mathrm{S}_{100^{\circ} \mathrm{c}}$ which holds the highest amount is 4.41 percent weight and the $\mathrm{S}^{\prime}{ }_{100^{\circ} \mathrm{c}}$ phase which holds most efficient extraction contains1.18percent weight impurities. The amoun of NMP in $\mathrm{S}_{100^{\circ} \mathrm{c}}$ and $\mathrm{S}_{100^{\circ} \mathrm{c}}$ are similar, therefore, it can be said that n-heptane is very selective toward NMP and doesn't extract impurities. 
Table 4. Summary of the NMP extraction in n-heptane in different temperatures

\begin{tabular}{ccccc}
\hline $\begin{array}{c}\text { Extraction } \\
\text { temperature }{ }^{\circ} \mathrm{C}\end{array}$ & NMP efficiency & Total efficiency & \%sample extraction & \%NMP by weight \\
\hline 25 & 5.53 & 10.49 & 0.5185 & 9.80 \\
70 & 21.64 & 40.79 & 2.1723 & 85.68 \\
100 & 53.26 & 64.23 & 5.0589 & 90.69 \\
\hline
\end{tabular}

Shows the summary of the different temperatures used. As it can be seen with the increase in temperature more of the residue is dissolved in n-heptane also more NMP is extracted which results in the increase of the efficiency of the process.

\section{Optimization of the extraction by increasing solvent residue ratio}

Once the optimum temperature was determined, it was necessary to determine the effect of solvent residue ratio on the efficiency of the extraction. Four sets of weight percent rations 1:1, 2:1, 4:1, 6:1 were prepared in such a way that 10 gr. residue and equal or increasing amount of $n$-heptane were mixed at $100 \mathrm{c}$. There was no separate phase formation as previous sections, however, as the mixture mixed at 100c. There was no separate phase formation as previous
cooled phases began to form. The results are summarized in table 5 .

Table 5. n-heptane extraction of NMP in different ratios.

\begin{tabular}{cccccc}
\hline $\begin{array}{c}\text { Solvent residue } \\
\text { ratio }\end{array}$ & NMP efficiency & Total efficiency & $\begin{array}{c}\text { Weight of } \\
\text { extracted } \\
\text { sample }\end{array}$ & $\begin{array}{c}\text { \%NMP by } \\
\text { weight }\end{array}$ & $\begin{array}{c}\text { \%Impurity by } \\
\text { weight }\end{array}$ \\
\hline $2: 1$ & 53.26 & 64.28 & 5.0589 & 90.69 & 1.55 \\
$4: 1$ & 47.66 & 77.73 & 4.4521 & 92.23 & 0.59 \\
$6: 1$ & 30.43 & 83.38 & 3.2001 & 82.28 & 0.37 \\
$8: 1$ & 25.27 & 85.29 & 3.0101 & 81.15 & 0.31 \\
$9: 1$ & 20.18 & 86.97 & 2.9862 & 80.27 & 0.28 \\
\hline
\end{tabular}

As it evident from the table, with the increase in solvent, total efficiency is also increased, ho(never wever, becar No perature, the NMP solvent thus reduces NMP weight percent which is our goal. However, at higher solvent-residue ratio, this process renders inefficient with an intangible reduction in total efficiency and NMP weight percent Therefore, a 6:1 solvent ratio seems to be optimum, and since this ratio tends to hold the highest acceptable total efficiency, and since the separation of NMP and n-heptane both having two very different boiling points, this method could save large amount of very valuable solvent.

\section{REFERENCES}

[1] R.W.Phillips, Chemical Cleaning and surface Preparation in Aqua and Solvent Based Processes, Marrich Associates, 2000 .

[2] J.M Butter, etal, Water Miscible cleaning of Printed Wire Assemblies Proceedings of Inter CFC\& Halton Alter conference Oct, 93 .

3] N-Methylpyrrroliodone, storage and handling BASF corp. mount olive, New Jersey, UAS 1999.

[4] C.J., Camenup, et at Toxico Lett. 162(2,3)139-45,2006 [5] S.T.Chow, T.L.Ng, The Biodegradation of N-Methyl, 2-Pyrrolidone in water by sewage bacteria. Water Research, vol. 17 117-118,1983.

6] S.Matsui, T.Murokimi, T.Saski, Activated sludge degradation of organic substance in the waste water of kashima petroleum, and Petro. Chemical Industrial Complex in Japan, Progress in Water Technology, Vol 7, P.645-659,1975.

[7] P.Akril, J.Croker, S.Dixon, Dermal Exposure to Aqueous Solutions of N-Methyl Pyrrolidone, Toxicol, Lett., 134, 265269,2002 